\title{
The Effectiveness of Physics Learning Online Based on Guided Discovery Models to Improve Critical Thinking Skill
}

\author{
Eko Mhd Ramadan ${ }^{1, *}$ Jumadi Jumadi $^{2}$, Dwi Ulan Rahmawati ${ }^{3}$ \\ ${ }^{1}$ Graduate Student of Physics Education, Yogyakarta State University, Indonesia \\ ${ }^{2}$ Sains Education Department, Yogyakarta State University, Indonesia \\ ${ }^{3}$ Graduate Student of Physics Education, Yogyakarta State University, Indonesia \\ *Corresponding author. Email ekomhd.2015@stundent.uny.ac.id
}

\begin{abstract}
Critical thinking skill is one of the abilities that must be possessed by students in the 21st century. Online learning combined with guided discovery models, is intended to be able to improve students' critical thinking skills at the high school level. This study aims to look at the effectiveness of online learning based on guided discovery models on the material of momentum and impulses to improve the critical thinking skils of high school students in class $\mathrm{X}$. The research method uses quasi experimentation. The results of the study for experimental class 1 with the help of the LMS Schoology effect size score of 1.971758665 in the high category and experimental class 2 with the help of WhatsApp Application Group effect size score of 2.12844972 in the high category.
\end{abstract}

Keywords: online learning, guided discovery, critical thinking, momentum and impulse.

\section{INTRODUCTION}

Answering the challenges of the development of the 21 st Century which is increasingly rapid, the need for learning that is designed to be able to practice the ability of the 21st Century. The ability to think critically is one of the six elements of 21st Century abilities that must be possessed by students [1]. The learning process in the 21 st-century competence in the use of the internet requires students to be directly involved, not just limited to searching for information but students can carry out learning online [2].

The expansion of technology in the current era called the 4.0 Revolution-era provides many changes in every aspect of life including in improving the quality of education [3]. Technology as a facility for students and teachers to have classes without face-to-face meetings but with online classes using all kinds of products from technology [4], [5]. Nowadays, the use of computers and the internet is done easily and quickly to convey learning material information via email, web sites, and online learning systems [3], [4].

Data from the Ministry of Education and Culture in 2018, the total number of middle and high school students is 14.9 million students. 7 million middle and high school students in Indonesia have studied online with various applications [6], [7]. The low level of adjustment of online learning and the importance of interaction between teacher-students and between students in the classroom have suggested that online learning alone may not be the most effective strategy for teaching and learning [8]. But with the presence of the teacher can be as a facilitator to set the learning agenda and illustrate how online activities can work effectively [9], [10].

An online learning system is a new system in education that utilizes information technology to support the learning process [11], [12]. The design of online learning models is distinguished by several types, one of which is a class learning model which is divided into two, namely using class teaching records and using a learning management system (LMS) [13]. The design model uses special software called a Learning Management System or LMS. This LMS is designed to replicate/imitate virtual/virtual classrooms where facilities ('spaces') are available to upload learning materials, discussions, assignments, assignment assessments, etc. needed for a learning activity [14].

The spread of pandemic diseases in the world including in Indonesia caused by SARS-Cov2 known as Coronavirus disease (COVID-19) which is vulnerable to children so it does not allow learning to be done face-to- 
face to prevent transmission of the COVID-19 virus [15], [16]. If online learning is well designed, delivered, and packaged, students can learn effectively and get significant results compared to unplanned and wellstructured online learning. [17].

Guided discovery model, namely learning begins with the instructions of the teacher with the syntax starting from the core questions, the teacher asks various questions that track intending to direct students to the expected conclusion, then students conduct experiments to prove the opinions expressed [18]. Learning with the discovery model requires teachers to be more creative and students more active in creating an atmosphere of discovery learning independently [19].

Momentum and impulse material is compulsory material taught according to the 2013 curriculum at the level X of the Mathematics and Natural Sciences High School. However, the results of HOTS (high order thinking skills) student learning is still very low [20]. Physics learning by combining face-to-face learning with online learning (Blended learning) can improve students' critical thinking skills [21]. Physics learning in sub-material types of collisions assisted by LMS Edmodo can improve students' critical thinking skills [22].

\section{RESEARCH METHOD}

This study uses a quasi-experimental method with Pretest-Posttest Control Group Design can be seen in table 1. The sample consisted of 2 class X Mathematics and Natural Sciences State High School 1 Ngemplak, experimental class 1 amounted to 35 students and experiment class 2 amounted to 35 students. The experimental class 1 was treated using LMS Schoology and the experimental class 2 was treated 2 using WhatApp Group Application. Assessment of critical thinking skills is done twice, namely the pretest and posttest using essay questions. Critical thinking ability data in the form of pretest and posttest graph of each indicator of critical thinking ability, results of Multivariate Normality data, Homogeneity Test results, Correlation Analysis results, and Effectiveness Scale Tests [23].

Table 1. Experimental design

\begin{tabular}{c|c|c|c}
\hline Class & Pretest & Treatment & Posttest \\
\hline Experiment 1 & $\mathrm{O} 1$ & $\mathrm{X}$ & $\mathrm{O} 2$ \\
\hline Experiment 2 & $\mathrm{O} 1$ & $\mathrm{Y}$ & $\mathrm{O} 2$ \\
\hline
\end{tabular}

Description; X: LMS Schoology-assisted online learning, Y: WhatsApp Group Application assisted online learning.

\section{RESULT}

After 3 weeks of giving treatment, students carry out a posttest to see the effect of online learning based on guided discovery models on students' critical thinking skills. Posttest was carried out in the experimental class 1 and experiment 2, then the posttest results obtained were combined with the pretest results in the graph. The results of the pretest and posttest of the experimental class 1 can be seen in graph 1 and the results of the pretest and posttest of the experimental class 2 can be seen in graph 2.

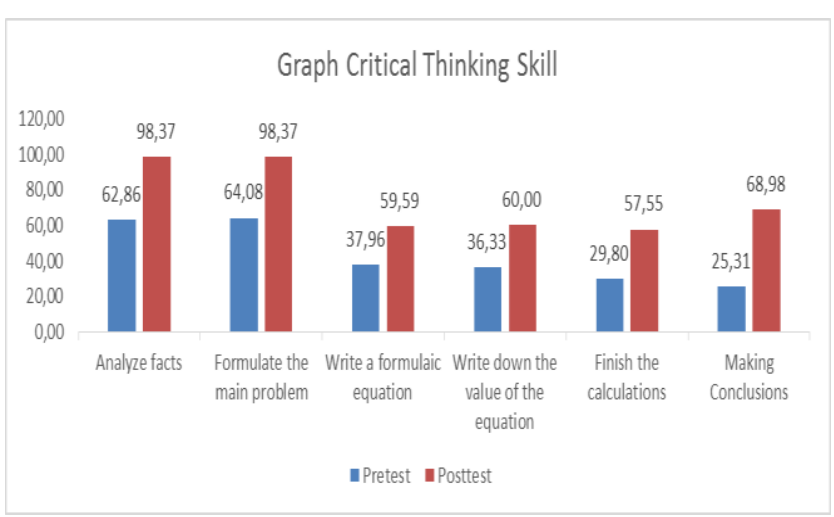

Graph 1. The results of the comparison of the pretestposttest value of critical thinking skills of the experimental class 1

Based on graph 1 it can be seen that there is an increase in the ability to think critically based on existing indicators.

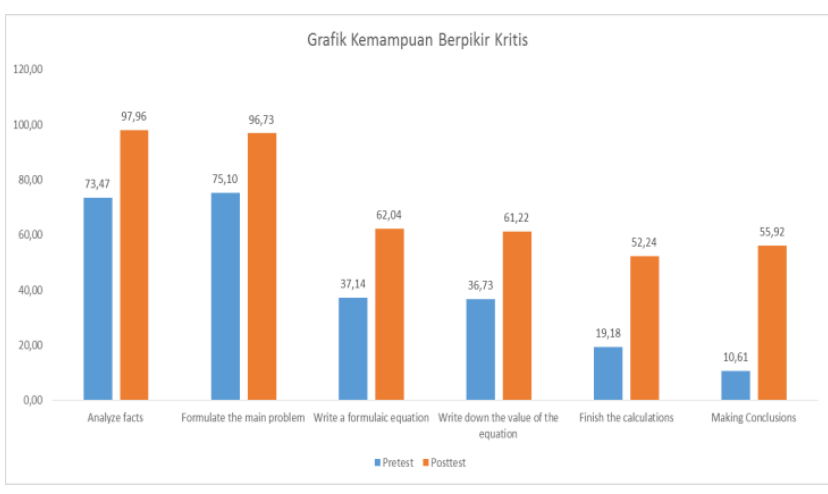

Graph 2. The results of the comparison of the pretestposttest value of critical thinking skills of the experimental class 2

Based on graph 2 it can be seen that there is an increase in the ability to think critically based on existing indicators. However, if you look at the comparison with the results of experimental class 1 , it appears that the posttest value achieved is almost the same.

Testing the effectiveness of online learning, then first tested the requirements of multivariate data normality and homogeneity of data to adjust the further tests that must be done. The results of the effectiveness test are as follows:

Multivariate normality data obtained from the chisquare value, with the results can be seen in table 2 . 
Table 2. Multivariate normality test

\begin{tabular}{c|c|c}
\hline & & Chiq \\
\hline Pretest & Sig. (2-tailed) & 0,000 \\
\hline Posttest & Sig. (2-tailed) & 0,000 \\
\hline
\end{tabular}

Based on table 2, it is known that the value of sig 0.00 , which is sig $<0.05$. Based on this, then $H_{0}$ is accepted, multivariate normality data distribution.

Homogeneity data is taken from the students' posttest values with the results can be seen in the Levene's Test of Equality of Error Variances table. Homogeneity can be seen in table 3 .

Table 3. Homogeneity Data

\begin{tabular}{c|c}
\hline Measuring Variable & Sig. \\
\hline Critical Thinking & 0,276 \\
\hline
\end{tabular}

Based on the data obtained, it is known that the significance value of critical thinking skills is 0.276> 0.05 so that the data is homogeneous. Based on these values the normality and homogeneity of data requirements are met, then test the effectiveness scale by calculating the effect size values as follows:

Table 4. Paired samples statistics experimental class 1

\begin{tabular}{ll|r|r|r}
\hline \multicolumn{2}{c|}{ Critical Thinking } & Mean & N & $\begin{array}{c}\text { Effect } \\
\text { Size }\end{array}$ \\
\hline \multirow{2}{*}{\begin{tabular}{ll|r|r} 
Pair \\
1
\end{tabular}} & $\begin{array}{l}\text { Pretest value of } \\
\text { critical thinking }\end{array}$ & 43,17 & 35 & 1,97175 \\
& $\begin{array}{l}\text { Posttest value of } \\
\text { critical thinking }\end{array}$ & 73,89 & 35 & \\
\hline
\end{tabular}

Based on the data in table 4, it is known that the effect size value is in a large category, which means that treatment gives a large contribution to the effectiveness of critical thinking skills.

Table 5. Paired samples statistics experimental class 2

\begin{tabular}{|c|c|c|c|c|}
\hline & tical Thinking & Mean & $\mathrm{N}$ & Effect Size \\
\hline \multirow[t]{2}{*}{$\begin{array}{l}\text { Pair } \\
1\end{array}$} & $\begin{array}{l}\text { Pretest value } \\
\text { of critical } \\
\text { thinking }\end{array}$ & 42,14 & 35 & \multirow[t]{2}{*}{$\begin{array}{r}2,128 \\
44972\end{array}$} \\
\hline & $\begin{array}{l}\text { Posttest value } \\
\text { of critical } \\
\text { thinking }\end{array}$ & 71,37 & 35 & \\
\hline
\end{tabular}

Based on the data in table 5, it is known that the effect size value is in a large category, which means that treatment gives a large contribution to the effectiveness of critical thinking skills.

\section{DISCUSSION}

The application of online learning based on guided discovery models on the material of momentum and impulses can improve the critical thinking skills of students in grade X MIPA high school. So the experimental research that has been done can find out the effectiveness of online learning based on guided discovery models to train students' critical thinking skills. Based on table 4, it is known that the effect size value for online learning assisted by LMS Schoology is 1.971758665 . While. Table 5 shows the value of the effect size for online learning aided by the WhatsApp group application of 2.12844972. Effect size values obtained in different treatments are included in the large category with a range of effect size values $\geq 0.8$ including large criteria [24].

The results obtained in this research are not optimal because there are several limitations and shortcomings. The need for students to habituate and adapt to online learning based on guided discovery models assisted by LMS Schoology and WhatsApp group application can be one of the causes of not achieving maximum learning outcomes. Then the need for further research that requires at least 6 months to see an increase in the ability of students and get good results [25].

Each class experiences an increase in critical thinking skills on all indicators. However, there are significant differences in the pretest scores in the experimental class 2 using WhatsApp media application scapegoat compared to the experimental class 1 using LMS Schoology, where the pretest scores in the experimental class 2 have higher scores on several indicators. After being given teaching materials in the form of LKPD and handouts based on guided discovery models and the same treatment that is by online learning both classes have increased in the assessment of critical thinking skills. The application of guided discovery models in the learning process can improve students' critical thinking skills [26]. The use of guided discovery-based handouts in learning at the high school level can improve students' critical thinking skills [27]. Using LKPD based on guided discovery models on complex and complex material can improve participants' learning outcomes [28].

Motivation is action from within students that is needed to foster a sense of learning so that learning motivation is always awake during learning [29]. it is necessary to adjust the use of instructional media to the learning styles and needs of students [30]. There are different motivations and learning styles of students during the learning process causing learning outcomes that are not optimal. 


\section{CONCLUSION}

Based on the results of the study, it can be concluded that online physics learning based on guided discovery models on momentum and impulse material is effective for training and improving critical thinking skills of high school level $\mathrm{X}$ class students. The use of online physics learning devices based on guided discovery models can be used as consistent and sustainable as a learning solution when certain conditions require teachers and students to do learning without face to face.

\section{ACKNOWLEDGMENTS}

The author sends his thanks to Prof. Dr. Jumadi, M.Pd. as a supervisor of this study and the State High School 1 Ngemplak, especially for students of class X MIPA 1 and MIPA 2 in 2019.

\section{REFERENCES}

[1] Triling B and Fadel C 2009 21st Century Skills Learning For Life In Our Times, 1st ed. (San Francisco, California: Jossey-Bas)

[2] Wijayanti W., Maharta N, and Suana W 2017 Pengembangan Perangkat Blended Learning Berbasis Learning Management System pada Materi Listrik Dinamis J. Ilm. Pendidik. Fis. AlBiruni, vol. 6, no. 1, pp. 1

[3] Qomariyah S, Gunarhadi, and Rejekiningsih T 2018 Edmodo in Blended Learning to Increase Language Learners' Understanding in Learning Grammar for Toefl Int. J. Educ. Res. Rev., vol. 4, no. 1, pp. 82-87

[4] Rahmi U, Jasrial J, Ansyar M, and Effendi Z M 2018 The Development of Message-Design Model in Blended Learning Asian J. Technol. Manag. vol. 10, no. 1, pp. 1-9

[5] Trinder R 2015 Blending technology and faceto-face: Advanced students' choices $\operatorname{ReCALL}$, vol. 28 , no. 1 , pp. 83-102

[6] Kemendikbud, 2018 Laporan Jumlah Siswa SMP dan SMA di Indonesia Tahun 2018 (Jakarta: Kemendikbud)

[7] Usman S 2018 Sekolah masa depan di era digital belajar dan mengajar di mana saja, the conversation (Jakarta: Kompas)

[8] Reich J 2015 Rebooting MOOC Research: Improve assessment, data sharing, and experimental design Science (80-. )., vol. 347, no. 6217, pp. 34-35

[9] Johnson W L and Lester J C 2016 Face-to-Face Interaction with Pedagogical Agents, Twenty Years Later Int. J. Artif. Intell. Educ., vol. 26, pp. 25-36

[10] Paskevicius M and Bortolin K 2016 Blending our practice: using online and face-to-face methods to sustain community among faculty in an extended length professional development program Innov. Educ. Teach. Int., vol. 53, no. 6, pp. 605-615

[11] Susilo P H and Rohman M G 2019 Sistem Pembelajaran Online Berbasis Aplikasi Web Menggunakan Framework Codeigniter Joutica, vol. 4, no. 2, p. 281

[12] Susilo P H and Rohman M G 2019 Efektivitas sistem pembelajaran online sebagai media pembelajaran berbasis aplikasi web di era milenial Semin. Nas. Sist. Inf.

[13] Bates A W 2015 Teaching in a Digital Age Second Edition in Quarterly Review of Distance Education, vol. 16, no. 4, Vancouver, B.C: Tony Bates Associates Ltd, p. 99

[14] Belawati T 2019 Pembelajaran Online. (Banten: Universitas Terbuka)

[15] Rothan H Aand Byrareddy S N 2020 The epidemiology and pathogenesis of coronavirus disease (COVID-19) outbreak J. Autoimmun., vol. 109, no. February, p. 102433

[16] Yuliana 2020 Corona virus diseases (Covid 19); Sebuah tinjauan literatur Wellness Heal. Mag., vol. 2, no. 1, pp. 187-192

[17] Clark R C and Mayer R E 2011 E-learning and the science of instruction: proven guidelines for consumersand designer of multimedia learning 2th Edition. (United States of America: Wiley \& Sons, Inc)

[18] Hanafiah N and Suhana C 2012 Konsep Strategi Pembelajaran, Ketiga. (Bandung: PT. Refika Adiatama)

[19] Sani R A 2013 Inovasi Pembelajaran. (Jakarta: Bumi Aksara)

[20] Afifah A W, Faizaha A, and Aminah N S 2018 Students ' Conception on Momentum and Impulse toward Higher Order Thinking Skill 5th ICRIEMS Proc., pp. 50-55

[21] Anggraeni A, Supriana E, and Hidayat A 2015 The Enhancement of Students' Critical Thinking Skill on Heat and Temperature through Blended Learning pp. 1-8

[22] Ramadan E M, Jumadi, and Astuti D P 2020 Application of e-handout based on PhET simulation to improve critical thinking skills and learning independence of high school students," J. Phys. Conf. Ser., vol. 1440, no. 1

[23] Sugiyono 2010 Metode Penelitian Kuantitatif Kualitatif dan $R \&$ D . (Jakarta: Alfabeta)

[24] Cohen J 1988 Statistical power analysis for the behavioral science in 2th edition, 2th ed. (United States of America: Lawrence Erlbaum Associates)

[25] Suwono H, Adi W C, and Suarsini E 2019 Guided inquiry-blended learning (GI-BL) to enhance the critical thinking skill of undergraduate biology students AIP Conf. Proc., vol. 2081, no. March, pp. 0-7

[26] Purwanto C E, Nughoro S E, and Wiyanto 2012 Penerapan Model Pembelajaran Guided Discovery Pada Materi Pemantulan Cahaya 
Untuk Meningkatkan Berpikir Kritis UPEJ (Unnes Phys. Educ. Journal), vol. 1, no. 1

[27] Suryani N T, Prayitno B A, and Rinanto Y 2018 Pengembangan Modul Berbasis Guided Discovery Pada Materi Sistem Pernapasan Untuk Meningkatkan Kemampuan Berpikir Kritis Siswa Kelas XI Sma Negeri 5 Surakarta," INKUIRI J. Pendidik. IPA, vol. 7, no. 1, p. 101

[28] Estuningsih I S, Susantini E 2013 Pengembangan Lembar Kerja Siswa (LKS) Berbasis Penemuan Terbimbing (Guided Discovery) untuk Meningkatkan Hasil Belajar Peserta Didik Kelas XII IPA Sma Pada Materi Substansi Genetika BioEdu, vol. 2, no. 1, pp. 27-30

[29] Gullu H and Delialioglu O 2018 The effect of learning environment factors on students' motivation and learning J. Learn. Teach. Digit. Age, vol. 3, no. 2, pp. 12-21

[30] Yusuf I, Widyaningsih S W, and Purwati D 2015 Pengembangan perangkat pembelajaran Fisika Modern berbasis media laboratorium virtual berdasarkan paradigma pembelajaran abad 21 dan Kurikulum 2013 Pancar. Pendidik., vol. 4, no. 2, pp. 189-200. 